\title{
EDITORIAL REMARKS
}

\section{A new journal based on an old idea}

With this issue, Cambridge University Press inaugurates a new journal based on an old idea. Since Seler, and more formally since Kirchhoff's day, scholars have viewed Mesoamerica as a region that is culturally diverse, yet at the same time integrated by bonds of history, economy, and religious belief. Here is perhaps one instance in which a term has proved more useful than its authors ever imagined; most of us were trained as Mesoamericanists, not Belizean Mayanists or Tabasqueño Olmecistas, and from graduate school on our respect has deepened for the richness and sheer bibliographic depth of the region. The large and growing number of Mesoamerican specialists suggests that many feel the same way.

But there is also much that troubles us, particularly in recent years, when it has become increasingly acceptable to lose sight of Seler and Kirchhoff's vision and to focus on a small corner of Mesoamerica, even a particular valley or shoreline, missing entirely the panoramic sweep of Mesoamerican antiquity. This seems to us a sad thing and, worse yet, a prelude to intellectual triviality and inadequate scholarship. Ancient Mesoamerica is our response to the fragmentation of the discipline. With this journal, we wish to emphasize once again the integral nature of the region and to provide a forum for those who want to explore, in an interdisciplinary fashion, the many ethnographic, linguistic, archaeological, and historical dimensions of the Mesoamerican past. At the same time we hope to promote rigorous scholarship, but in jargon-free and readable prose that even the educated layman can understand.

The organization of the present issue is designed to accommodate as many different points of view and research topics as possible - anything relevant to ancient Mesoamerica will find, after suitable review, a ready home in Ancient Mesoamerica. We have included methodological articles, theoretical articles, and reports on field research, as well as a special section deal- ing with an important and topical theme in Mesoamerican studies.

In this issue we present recent thoughts on the Mixtec codices, as researched by an ethnographer, an historian, a linguist, and two archaeologists. The other contributions range widely over not only archaeology and related fields, but space and time. Messenger and Hayden and Gargett present provocative arguments touching on climate and social evolution, respectively. Manzanilla and Barba and Smyth explore the Mesoamerican household from converging perspectives. Moholy-Nagy and Nelson report on lithic analyses from the important Maya site of Tikal. And in a remarkable article on a veritable New World Pompeii-the Classic site of CerénPayson Sheets and his team show that tragic events are nothing new to El Salvador; their article builds considerably on earlier work at the site by Zier and Sheets himself. Finally, Federico Fahsen offers insights on the most complex writing system in the Americas, that of the ancient Maya.

We close with a note of thanks to the many people who have made this journal possible, particularly James Alexander of Cambridge University Press, without whose foresight and prudent advice this undertaking would not have been possible. Christopher Chippindale, editor of Antiquity, provided a sensible and balanced perspective on what it takes to edit a journal, and we have made heavy use of his example and counsel. Several anonymous reviewers also helped by agreeing that a journal on Mesoamerica might not be a bad idea. Finally, and not least, we thank our authors for their good grace in the face of tight publication deadlines and querulous editors.

William R. Fowler, JR. STEPHEN D. HoustoN 


\section{ANCIENT MESOAMERICA Forthcoming Papers}

The Decipherment of "Directional Count Glyphs" in Maya Inscriptions David Stuart

Department of Anthropology, Vanderbilt University

New Findings on the Origins of Thin Orange Ceramics

Evelyn Childs Rattray

Instituto de Investigaciones Antropologicas, Universidad Nacional Autonoma de Mexico

\section{Who Was Who in Ninth-Century Chichen Itza}

William M. Ringle

Department of Anthropology and Sociology, Davidson College

A Reexamination of the Compositional Affiliations of Formative

Period Whiteware from Highland Guatemala

Hector Neff, Ronald L. Bishop, and Dean E. Arnold

Conservation Analytical Laboratory, Smithsonian Institution

Long Distance Trade Under the Aztec Empire:

The Archaeological Evidence

Michael E. Smith

Department of Sociology and Anthropology, Loyola University of Chicago

Small-Scale Maya Lime Making in Belize: Ancient and Modern

J. Jefferson MacKinnon and Emily M. May

Shimer College 